\title{
A NEIV AND OLD READING ON THE FOURTH SECTION OF THE STATUTE OF FRAUDS.
}

"IIercin. though I could not be innorant of the difficulty of matter, which he that takcth in hand shill soon find, or much less of my own unableness, which I had continual sense and feeling of; yet because I had more means of absolution than the younger sort, and more leisure than the greater sort. I did think it not inpossible to work some profitable effect; the rather beciuse where an inferior wit is bent and conversant upon one subject. he sliall many times with patience and meditation dissolve and undo many of the knots, which a greater wit distracted with many matters would rather cut in two than unknit: And at least if my invention or judgment be too barren or 100 weak; yet by the benefit of other arts, I did hope to dispose or digest the authorities or opinions * * * in such order and method, as they should take light one from another, though they took no light from me."-Sir Francis Bacon's Reading on the Statute of Uscs.

It is one of the clementary rules for the construction of statutes altering the Common Law that technical words of law are presumed to have been used in a technical sense; in other words, that the legislature is presumed to have understood the old law, the mischief of which they intended to remedy.

It is another equally well established rule that in construing such statutes the courts should have regard to the old law, the mischief, and the remedy, and they should so construe the statute as to suppress the mischief and advance the remedy. In doubtful cases where the application of either of the above rules would lead to a conclusion contrary to that produced by the application of the other-the technical meaning of words being at war with a just and reasonable legislative intention-the technical meaning of the words should be abandoned.

Where, however, giving technical terms their full effect they produce in all cases only just and reasonable results in their application to the mischief to be remedied, this interpretation of the legislative intention is most probably correct.

To rightly interpret that sub-section of the fourth sec- 
tion of the statute of frauds. which declares that "no action slall be brought upon any special promise to answer for the debt, default or miscarriage of another person," etc., the writer submits that we should first ascertain whether the statute contains technical terms, $i$. e., terms having a definite meaning to the lawyers of the Restoration; and, sccond, after determining the old law and the mischief apply the statute so as to remedy the mischief.

If the statute read, "No action shall be brought upon any contract to answer for the debt, default, etc., of another, etc.," or, "No action shall be brought upon any agreement to answer for the debt, etc., of another," this language to the minds of many lawyers of the present day would be the equivalent of that employed by the British Parliament, in 1677 . But those words are not the words of the $\Lambda$ ct. Did the words employed by the framers of the act-" no action shall be brought upon any special promise to answer for the debt, default, etc., of another person"-mean anything different? If the term "special promise" had no different meaning, why was it employed? If the terms "contract" and "agreement" mean the same thing as "special promise" why was neither of those words here employed?

Section 4 speaks of "agrccments made upon consideration of marriage" and of "contract or sale of lands." The terms "agreement" and "contract" were therefore familiar in the law of the seventeenth century. Was it by mere chance or was it by design that they were not used and the term "special promise," was employed in announcing the legislative prohibition of a parol guaranty?

Professor Ames, is the first writer of our day who has attempted to restore the significance of the distinction between a debt and a special promise in the interpretation of the statute of frands. In a brief but suggestive passage,

\footnotetext{
"The distinction between Debt and Special Assumpsit, as illustrated in the cases mentioned in the preceding paragraph, is of practical value in determining whether a promise is in certain cases within the Statute of Frauds relating to guaranties. If $B$ gets the enjoy-
} 
he shows that where the promise is contemporaneous with the original credit, the question whether or not the statute applies is solved by answering the question whether a special promise or a debt has been created. In the former alternative, the statute applies because the statute bars action upon any verbal "special promise." In the latter alternative, though a parol debt may have been created, the statute has no application, because the English Parliament, in 1677 , said nothing about parol debts in Section 4 (except marriage agreements) and did not deprive the creditor of a remedy thereon except as provided subsequently in Section 17.

It is not, however, the writer's purpose to dwell longer at present on the above well recognized distinction ${ }^{2}$ than is necessary to make it serve as a picce of evidence in support of the thesis of this paper.

All promises to pay the debt of another are either of

ment of the benefit furnished by the plaintiff at $A$ 's request, but $A$ is the only party liable to the plaintiff, A's promise is not within the statute. If, on the other hand, $B$ is liable to the plaintiff for the benefit received, that is, is a debtor, A's promise is clearly a guaranty and within the statute." - VIII Harvard Law Review, pp. 263-264.

'A further discussion and application of this distinction to American cases will be found in Professor Ames' Cases on Surctyship, pp. I, 2, 3, 4 and notes; also in the writer's "Leading Cases on the Fourth Section of the Statute of Frauds," pp. I2-20. On the early English cases before the statute see Hare on Contracts p. 122.

Prior to the statute the action on the case was very commonly brought ex. g., "in consideration that the plaintiff would deliver unto the defendant's son such wares, etc., did assume and promise unto the plaintiff that he would pay the plaintiff for them, etc." There was judgment for plaintiff. Johnson v. Abington, Styles 163 (1649). Imincdiately after the statute this distinction controls the decisions. Anonymons, I Vent. 293 ( I677) ; Anderson v. Hayman, I H. Bl. I20 (1789).

Though courts have generally adhered to this test and said that the sole credit must be given to the defendant in order to render him liable on his promise to pay for goods delivered to or services rendered to another. Ames' Cases on Suretyship, p. 3, note 2, the reason for the distinction as pointed out by Professor Ames has however gradually faded out of the judicial consciousness.

The gradual obliteration of the distinction between a debt and a special promise may be seen from the language of Wood L. C. B. in Cope v. Joscph, 9 Price, at p. 160 (1821).

It will be hereinafter contended that in the humble judgment of the writer the distegard of this distinction produced an erroneous decision in Sutton v. Grey, L. R. I, Q. B. 285 (I893). 
class $(A)$ : promises made when the debt of the other person is contracted; or of class (B): promises made afterwards-to pay a pre-existing debt. As above stated, Professor Ames has directed attention to cases of class (A) and has referred to numerous decisions showing that the English courts in the time of the Restoration and later held that if by a parol transaction the defenclant became a deblor, the statute had no application, but that if the defenclant became a special promisor, to answer for any credit given to another, the statute applies.

But why should we not also examine cases of class (B) in the light of the contract law contemporaneous with the statute?

It has been aptly said by Comstock, C. J. in Mallory v. Gillett, 2 I N. Y. 4 I2 (1860):

A novation. $i . c$. where the pre-existing debt is extinguished simultancously with the creation of the new, is plainly outside the statute.

"The statute points to no distinction between a debt created at the time when the collatcral engagement is made, and one having a previous existence. The requirement is, that promises to answer for the debt, \&c., of a third person, be in writing. The original and collateral obligations may come into existence at the same time, and both be the foundation of the credit; or the one may exist and the other be created afterwards. In either case, and equally in both, the inquiry under the statute is, whether there be a debtor and a surety, and not when the relation was created."

One naturally asks, were all contracts involving the payment of another's pre-existing debt "special promises to answer for the debt, etc., of another person"? If the defendant became liable as a debtor though the payment of this new debt would discharge another's preexisting debt the defendant would not be merely a special promisor. He would be liable as debtor. If the defendant became liable in the action of account he would not be merely a special promisor, he would be a bailee or receiver to ac- 
count, and therefore an accountant. If the defendant has become accountable to his bailor and the amount with which he is chargeable will go in discharge of the pre-existing debt of another person, the defendant is nerertheless a bailee or a receiver; $i$. $c$., an accountant, he is not merely making a special promise.

Consistency in interpretation requires that if a new debt, though parol, is created, which involves the payment of a prior debt of a third party, the statute has no application. If a new parol promise amounts to nothing but a special promise or assumpsit, though on a consideration sufficient to have supported an action prior to the statute, the statule bars recovery.

In other words, I submit that in the English law of Contracts at the date of the statute, there were three species of simple contracual liability, as later set forth in Buller's Nisi Prius (p. 126):

(I) Accountability, dependent upon a bailment.

(2) Debt, dependent upon quid pro quo, which might arise upon sale or loan or on some act done on request.

(3) Assumpsit or special promise dependent upon consideration.

I shall endeavor to show that the practical distinction between these three species of contract was the reason why the English Parliament endearoring, in 1677 , to suppress the perjurous falsification of parol guaranties denounced parol special promises or assumpsits but left untouched. parol debts, and parol accountabilities; and finally, it is proposed to show that the distinction thus marle by the British Parliament should still be preserved between these three species of contract in order to apply the statute to-day to the effective suppression of perjury.

The expression "special promise," etc., means special assumpsit. $^{\text {. }}$

\footnotetext{
On an "Assumpsit : . . that the defendant, in consideration that the plaintiff would forbear to procecd upon the capias utlugatum a assumed that if B did not pay the debt that he would pay it," the plaintiff obtained judgment in Jennings v. Harley, Cro. Eliz.
} 
A parol special promise to answer for the debt, etc., of innther person could be established by proving the defendant's inducing promise and the plaintiff's detriment (usually forbearance to sue the plaintiff's debtor). As forebearance was merely a passive state on the part of the creditor plaintiff, the perjurer or suborner of perjury could easily enable the plaintiff to recover by fabricating the defendant's promise and by showing the creditor's mere passivity thereupon. Parliament by the statute declared that no action should be brought "upon any special promise to

209 (44-45 Eliz.). So assumpsit lay in Rippon v. Norton, Cro. Eliz. 89I, in consideration of plaintiff's desisting from making any complaint to a justice of the pcace. So in "Assumpsit for that the defendant in consideration the plaintiff would forbear to stie one J. S., on an obligation . . . promised to pay, \&c." it was adjudged for the plaintiff in Mapes v. Sidncy, Cro. Jac. 683. So in "Assumpsit for that the testator was indebted ... and the defendant... assumed that if he forbore to sue him until such a time he would pay . . . it was adjudged for the plaintiff" in Fisher v. Richardson. Cro. Jac 47. In Therne v. Fuller, Cro. Jac. 396 , an assumpsit was successfully maintained on defendants promise to pay the debt of another "in consideration that the plaintiff at the defendants request... would assent and be content to desist from further prosecution of the said suit.". See I Rolle Abr. 27 pl. 49.

Rosyer brought "an action upon the case upon an assumpsit against L a femme administratrix, and declares that the defendant in consideration that he would forbear suit until she had taken out letters of administration. did assume and promise to pay. \&c." and recovered in Rosyrer v. Langdale. Styles, 248 ( 1650$)$. So in Finer v. Jeffry, Styles, 57 (1648). the plaintiff "brings an action upon the case against $\mathrm{J}$ and icclares. that the defendant did assume and promise unto him that if he would forbear to sue one who had assaulted him and beaten him that he, the defendant, would pay, \&c." and obtains judgment.

I651. Irume v. Iinton, Styles, 304. The creditor of the son obtains judgment against his mother in an action upon the case. Wherein the dcclaration averred that "she . . . did assume and promise unto the plaintiff that if he would stay for the money till Mich. next, that then she would pay it."

In Sheppard's Abridgment, Part I (London, 1675), the following use of the term special promise is made:

"That the contract or agreement that shall contain an assumpsit, and give an action upon the case upon it must be verhal, and not on a deed in writing. for this action will not lie upon a deed sealed and iclivered, nor for a rent on a deed nor upon an especialty or Record without some special promise made collaterally in the case. Croo. 2, 505. 565.668 ; Brownl. 2. II. I7; Owen, I63."

Thus in the Precedents by Sir Edward Lutwyche. Knight, Vol, I, p. 27t, lately one of the Judges of the Common Bench, London, 1704; "Ycoman v. Barstow, Trin, 13 W. 3 Regis, Narr. en Assumpsit sur special promise." 
answer for the debt, etc., of another person." All assumpsits based on consideration thenceforth became impossible of enforcement. Before the statute forbearance in any form whatever was only a consideration. Before the statute, forbearance to sue was never known to create a debt."

\footnotetext{
'In I422, in the Common Pleas, the plaintiff brought an action of debt on a promise to pay a judgment against ' $T$, the defendant, promising that he would become debtor for the said sum if the plaintiff would release his execution against $T$. Plaintift released his execution and the release was of record. Held, the promise was a nudum pactum. I Y. B., 9 H. V., page 14, pl. 23.

As to which case Brooke makes this illuminating gloss:

"It is seen that action on the case upon the promise lies, but not debt because there is not a quid pro quo." Brooke's Abridgment, p. 232 , no. 206.

See Sheppard's Abr. Title Debt reporting a similar and later case.

In Jordan's case, Y. B. 27, H. VIII Fol. 24, pl. 3 (Yetsweirt, London, I597), there was likewise a pre-existing debt and the Action on the Case was held to lie upon a promise to pay it in consideration of the debtor's discharge from prison.

The defense was made that debt would lie and not case. The Court held that debt would not lie.

Brook: "And besides as to that which has been said that the plaintiff shall have writ of debt and not this action, I am of a contrary opinion, for I understand that one snall not have writ of debt except where there is a contract for the defendant has not quid pro $q u o$, but the action is only based upon the promise."

The doctrine of Jordan's case that forbearance in any form could not create a debt has remained the law of England to the latest day. Harburg India Rubber Co. v. Martin, L. R. I, K. B. 778 (1902). In no form has forbearance ever been held to be the quid pro quo of a debt, and the only writ sucesssfully employed has been the action on the case on the contract of assumpsit. Rogers v. Snoze, Dalison, 94 (I5 Eliz.).

Some of the innumerable illustrations of forbearance promises (where the action on the case upon the assumpsit was successfully maintained) are the following:

Forbearance until Mfichaelmas gave rise to an Assumpsit in Thornton v. Kemp, Gouldsborough, I46 (Hilary Term, 43 Eliz.); a stay of execution against a third person on request of the defendant gave rise to an assumpsit in Jennings v. Hatley, Yelverton, I9 (44 \& 45 Eliz.).

An agreement by a pawnee not to scll the goods of his debtor for three days upon the defendant's promise to pay the debt. Capper v. Dickington, I Rolle Rep. 215 (I3 Jac. 1).

Thus a discharge of a debtor from imprisonment on request gave rise to an action on the case in Atkinson v. Settree, Willes' Reports, 482 (1744).

In 1653. Sheppard's "Faithful Counsellor; or, the Marrow of the Law in England," p. 226, thus emphasizes the fact that forbearance to sue will not create a debt:

"But if J. S. owe me money and another comes to me and intreat me to take him debtor for this money, and promise to pay me at Mich-
} 
Sir Matthew Hale, in Milton's case, stated unqualifiedly that "acceptance does not create a cluty, no more than a promise by' a stranger to pay' if the creditor will forbear his debt."

English courts have ever since 1677 consistently treated cases of forbearance as cases within the statute.

In the King's Bench, in 173I, "Raymond, C. J., held that a parol promise to pay the debt of another in consideration of forbearance, was void by the statute of frauds and perjuries."B

In 1797, Chater v. Beckett, ${ }^{7}$ presented the facts that the plaintiff had a special capias ad satisfacicndum against Har-

aclmas I cannot have this Action ( $i c_{e}$, Debt), upon this Contract, 9 H. $5,14.44$. Ed. 3,21 . If a man promise me twenty pounds to marry his daugliter, and I do marry her, I may have this Action for this Debt. F. N. B. 120."

The only intimation that the writer las found to the effect that forbearance could create a debt is in a case cited by Prof. Ames, in 8 Harv. Law Rep., p. 25I, Bediiell v. Catton, Hob. 216 (15 Jac.).

Even if this case was a distinct decision, I should hesitate, in view of the above anthorities, to believe the proposition that forbearance would create a debt. It appears, however, that in the case cited the action was not debt at all but Case, and that the quotation is a mere dictum. The point really decided by the case was that assumpsit in consideration of forbearance exccuted would lie against the executor upon the promise of the testator. The defendant's contention was that thougl the contract of debt would survive, assumpsit would not. The Court sustained the action against the executor by the argument that as debt was known to survive, assumpsit ought to survive, for that the assumpsit might have been based on as beneficial a consideration as the quid pro quo of a debt. The Court cited no authority to the cffect that forbearance created a debt and docs not so state or decicle but merely cites the familiar case of the creation of a debt in favor of a surgeon by his performing nedical services on request. It is common knowledge that the receipt of chattels or the performance of some physical act or service on request would always be a suffcient quid pro quo. The writer submits that the dictum is not entitled to even the weight given to it by Prof. Ames, for neither was the point inrolved, whether forbearance could create a debt, nor did the Court so state argucrdo.

Hardres, 485.

-I Strange, 1873 (1731). In Watcrs v. Glassop, I Ray, 357 (10 W. 3), there was a recovery on a promise to pay the debt of the son of the defendant in consideration of forbearance, but the statute does not appear to have been invoked and there is, in fact, nothing to show that the promise was parol.

'Durnford \& East, 201 (1797). 
ris, wherenpon in consideration that the plaintiff at the instance of the defendant would stay all further proceedings against Ilarris, and would accept certain bills of exchange drawn or accepted by the deiendant for a certain part, to wit, Ios. in the pound of his said clebt as a satisfaction for the whole, the defendant undertook and promised to give the plaintiff such bills for the same and to pay all the expenses which the plaintiff had been put to in and about the said intended commission, the writ, and the meetings of the creditors; that the plaintiff stajed all proceedings against Harris and accepted such bills, etc., jet that the defendant had not paid the said expenses or any part thereof."

Lord Kenyon, distinguishing the case from Read v. Nash 8 on the ground that in Riad v. Nash "Johnson was not a debtor, the case was not tried. . . Whereas in this case Harris was inclebted to the plaintiff and the defendant undertook to pay part of that debt and to pay certain other expenses," held the promise to be within the statute. Here there was nothing done but the exercise of forbearance and hence no debt:

In I821, Saunders v. Wakcficld, ${ }^{9}$ is another case of mere forbearance. The plaintiff agreed to forbear the prosecution of a pending suit against one Pitman and the defend-

I Wils. 305 (175I).

The plaintiffs testator Tuack had brought an action of assault and battery against one Johnson. Nash, the present defendant, being in court and the case being about to be tried, promised Tuack "in consideration that Tuack would not proceed to trial, but would withdiraw his record." to pay him $50 E$ and the costs in that suit to be taxed till the time of withdrawing the record. It was held that "Jolinson was not a debtor, the cause was not tried, lye did not appear to be guilty of any, default or miscarriage, there might have been a verdict for him, etc."

The writer stiggests as the correct explanation of this case that until the decision of Kirkham v. Mfarter, 2 Barn. \& Ald. 613 (1817), the word "miscarriage" in the statute was not supposed to include tortious liabilities.

' 4 B. \& Ald. 595 (1821). Accord: Tomlinson y. Gell, I N. \& P. 588 (1837), the consideration being a stay of proceedings by a solicitor in 2 suit in chancery. 
ant's verbal promise to pay Pitman's debt was held unenforceable.

In 1849 , in Gull v. Lindsay, ${ }^{10}$ the plaintiff, having merely the right to collect freight charges, abandoned that right in consideration of the defendants' promise to pay plaintiffs' commission to secure which the right to collect the freight charges had been assigned by the former owners, no debt was created as no property was transferred, and the plaintiff merely surrendered a chose in action.

Clearly distinguishable from the foregoing and entirely reconcilable therewith are the cases where the plaintiff having scized the body of his debtor on a ca. sa. lets him go at large upon the defendant's promise to pay the debt. Here there is a novation by the act of the creditor. The debt was discharged simultaneously with the creation of the defendant's assumpsit in Goodman v. Chase, I B. \& Ald. 297 (1818); Butcher v. Steuart, I I M. \& W. 856 (1843). The decision in Reader v. Kingham, I3 C. B. (N. S.) 344 (I862), holding that a promise to the bailiff of the creditor in consideration of forbearance was not within the statute when correctly understood presents no difficulty. The Court of Common Pleas rested the decision absolutely on the basis that the statute meant a promise to the creditor. Erle, C. J.: "The debt was due to Malins from Hitchcock: the promise was made to Reader. It has been distinctly settled, that, to bring the promise within the statute, the promisee must be the original creditor." Williams and Byles, J. J. delivered opinions to that same effect.

In Love's case (I Salkeld, 28; B. R. 5 Anne, abt. 1707), there was a pronise to a sheriff to pay the debt if the latter would restore the goods taken in execution. No question was made of the application of the statute and the plaintiff recovered.

The latest expression of judicial opinion in England is in Harburg India Rubber Co. v. Martin, L. R., I K. B. 778, a decision of the Court of Appeal, in 1902. Three of the

${ }_{4}^{10}$ Exch. 45 (1849). 
Lord Justices delivered quite extensive opinions reviewing previous decisions and concurring in the conclusion that the defendant, the stockliolder, and director of a judgmentdebtor-corporation, was not liable on his parol promise to pay the judgment made in consideration of the plaintiff's withdrawal of a writ of fieri facias.

The English courts from King v. Wilson, ${ }^{11}$ in 173I, down to Harburg India Rubber Co. v. Martin, in 1902,12 have steadily adhered to the doctrine that consideration consisting of forbearance in any form cannot remove a promise made to the creditor from the condemnation of the statute.

"It seems now to be everywhere agreed," says Professor Ames, "that a promise to a creditor to pay him the debt of another, in consideration of mere forbearance by the creditor is within the statute of frauds." ${ }^{13}$ The writer firmly believes that such ought to be the law everywhere; but unfortunately, some American decisions, wholly at variance with the above line of English cases, adopt as a criterion a question of fact requiring due process of judicial telepathy for its determination-whether the defendant's main or only his subordinate purpose was to pay the debt of another; and whether his main or only his subordinate purpose was to subserve some purpose of his own.

Into what an inextricable quagmire of doubt the decisions of Pennsylvania have sunk by adopting this criterion, the writer has endeavored to show in detail elsewhere. ${ }^{14}$ This supposed test is adopted in some other jurisdictions. ${ }^{15}$

${ }^{12} 2$ Strange, 873 (173I).

${ }^{23}$ L. R. I, K B. 778 (1902).

"Ames' Cases on Suretyship, p. 84, note X.

"Leading Cases on the Fourth Section of the Statute of Frauds, pp. $49,52,67,72$.

is Many American decisions, though containing dicla to the effect that a parol promise to pay the debt of another is enforccable "whenever the main purpose and object of the promissor is not to answer for another, but to subserve some peculiary or business purpose of his own, involving either a benefit to himself or damage to the other contracting party" will be found on scrutiny to be cases of bailments or receiverships to account. Thus the above italicized excerpt was 
In sharp contrast to the negative and passive character of a forbearance is the positive, physical and visible act of bailment.

At the clate of the cnactment of the statute the action of Account had been for sume four hundred years and still was a familiar remedy. Accountability, i. $c$., the duty to render a written accumnt concerning the defendant's disposition of chattels or money bailed (that is delivered), to him by the plaintiff, had been for ages past not only the appropriate and customary remedy, of the lord of the manor against his bailiff or of the ward against his guardian in socage but had also frequently been employed by a plaintiff against a defendant who was not his customary bailiff but his bailiff pro hac aice to sell goods or chattels and to render an account. The facts essential to constitute the duty to render an account were, (I) the delivery of chattels or money to the defendant; and, (2) his agreement to render an account to the plaintiff concerning his disposition thereof.

The liability of a defendant to account could never be established without proof of a bailment of money or goods to him. ${ }^{16}$ This physical transaction or the consequent physical change of possession with respect to the possession of the property could be seen and witnessed with comparative certainty on the part of bystanders or neighbors. Promises in consideration of forbearance on the contrary sounded in mere words and mental conditions, though perjury as to a bailment was of course conceivable. It would be

taken from a case where the defendant received securities "deemed by him and the company adequate, at the time, to indemnify him against his contract with the plaintiff." Recovery was permitted. Emcrson v. Sluter, 22 How. 28 (1859).

"Sheppard's Abridgnent, London, 1675. Title Accompt.

"What then are the facts which must exist in order to induce the law to raise an obligation to account? First, the person upon whom such an obligation is sought to be imposed (and whom we will call the defendant) must have received property of some kind not belonging to himself, for otherwise he will have nothing to account for or to tender an account of."-Professor langdell in II Harvard Law Review, pp. 243, 244 
more difficult to inluce witnesses to swear to the transfer of money or gools where none had been transferred than to induce them to paint and varnish a nere verbal recuuest for leniency so as to make it appear in court as a special promise to answer for the debt of another person.

Perjury as to a bailment or conveyance can sellom be successful. Res ipsa loquitur.

If the action of account, as above stated, was in common use at the period of the Restoration when the statute was passed, ${ }^{17}$ the silence of Parliament respecting a parol ac-

"In 3653 Sheppard's "Faithful Counsellor," \&c., page 23. thus stated the above familiar doctrine: "If I deliver to another money, corn or wares to account for, or to employ to any purpose . . - if it be not done and the thing not restored to me, I may recover it by this action;" $i$. e., by action of Account. See also Franklin's Case, Styles, 388 ( 1653 ).

In 1675 an action of account by church wardens against a late church warden and the declaration is printed in "The Attorney's Prac- tice in the Court of King's Bench," London, 1759.

Sheppard's Abridgment (London, 1675), Title Accompt.

In 31 Cas. II. an action of account by the executor of a merchant was brought against his factor as bailiff, and the declaration is printed at length, pp. 36, 37, of the last mentioned work.

In Tazedin v. Lavie, Lilly's Entries, p. I3 (1758), this declaration in account appears:

"James Tawdin, the younger, and James Frontin, executors of the last will and testament of James Tawdin, the elder, deceased, complain of Henry Lavie, merchant, being in the custody of the marslial of the Marshalsea of the Lord the King, before the King himscif, in a plea that he render to them a reasonable account from the time that he was bailiff of the said James Tawdin the elder, and receiver of the moncy of the said James in his lifetime, at Westminster in the county aforesaid, for this, to wit, that whereas the said IIcnry from the Ioth day of Mray in the 3ist year of the reign of the Iord Charles the second now King of England, \&c., until the 3oth day of Scptember in the $32 n d$ year of the reign of the said now Lord the King at Westminster in the county a foresaid, was bailiff of the said James the testator in his life-time, and for all the same time had the care and administration of divers goods and chattels of the said James Tawdin the elder, to wit, of two hundred thousand pounds of pewter, thirty firkins of stub-nails, two hundred and twenty-four pounds of spelter, forty thousand pounds of lead, and five hundred and fity pounds of tune glass, to the yalue of $£_{3000}$, to wit, at Westminster aforesaid in the county aforesaid, to merchandize and make profit thereof for the said James Tawdin the elder, and a reasonable account thercof to the same James the testator, when he should be thereunto required, to render, and receive of the monies of the said James Tawdin the elder, for the whole time aforesaid, and for the same time did receive of the monies of the said James Tawdin the testator, at Westminster aforesaid, by the hands of Peter Pontoise Err3 5d. 
countability involving the disclarge of another person's debt indicates an intention that no writing or memorandum of such transactions will be required. Likewise in common use was the action of debt, and its then comparatively recent and then modern remedial equivalent the action of Indebitatus Assimpsit. ${ }^{18}$

If $A$ bails his own goods to $B$, atthorizing $B$ to sell them and pay him, $A$, the proceeds, the bailee, $B$, is liable to $A$ in an action of account. ${ }^{19}$

If the plaintiff as creditor, having a lien by mortgage or pledge or a common law lien on chattels or having by levy acquired a lien on goods or lands of his debtor, subsequently transferred the property subject thereto to the defendant in pursuance of the latter's agreement to dispose of this property and apply the proceeds to the debt the defendant was clearly a bailee to account.

If instead of an agreement to apply the proceeds the defendant's promise was to pay a given sum to the plaintiff at all cvents, the defendant had made himself a debtor. ${ }^{20}$

and there by the hands of Peter Chabot $f_{9}$ and there by the proper hands of the said Henry Lavie fg60 of lawful noney of England; to render a reasonable account thereof to the said James the testator, when he should be theremto required: Nevertheless the said Henry Lavie, although often required, \&c. that reasonable account of the said James Tawdin the elder in his life-time, or to the same James Tawdin the younger and James Frontin, or either of them, after the death of the said James Tawdin the testator, hath not rendered but that to the said James the testator, and to the said James, now one of the plaintiffs, and James Frontin, after the death of the said James the testator, or to either of them, to render altogether hath refused, and that to the said James Tawdin the youmger, and James Frontin, and to either of them, yet to render doth refuse, to the damage of the said James Tawdin the younger and James Frontin $t_{10,000}$. And thetefore they produce the suit, \&e. And the same James Tawdin the younger, and James Frontin, produce here in court the letters testamentary of the said James Tawdin the testator, by which it sufficiently appears to the court here, that the said James Tawdin the younger, and James Frontin are executors of the testament of the said James Tawdin the elder, and thercof have the administration, \&c"

18 "The Limitations of the Action of Assumpsit, etc.," $56 \mathrm{Am}$. Law Register, 73.

"Viner's Abridgment Title Account (A) 5, I5, 32, (E) 20 . Sheppard's Faithful Counsellor, etc, p. 23.

${ }^{30}$ Professor Langdell in ii Harvard Law Review, p. 253; "Limitations of the Action of Assumpsit, etc.," 56 Am. Law Reg., P. 75. 
Having followed the line of English and American decisions whercin it has been consistently maintained that consideration consisting of forbearance to sue the principal debtor does not remove a parol promise to pay the debt of another from the operation of the statute we shall next examine the important decisions in which English and American courts have held promises to be outside the statute.

In I902, Lord Justice Vaughan-IVilliams ${ }^{21}$ speaking in the Court of Appeal of a certain group of these last mentioned cases referred to them as "property cases," saying, "in all those cases there was a larger matter which was the object of the contract." The position is taken by the present writer that all these so-called "property cases" will be found upon examination to be instances either of (a) the liability of the bailce of goods or receiver of monies to render an account; or, (b) of the liability known as a coinmon law debt.

Until I 766 -ninety years after the statute, when the well known case, 17 rilliams v. Leper, ${ }^{22}$ was decided there is a dearth of precedents. ${ }^{23}$ Here the goods of Taylor, the tenant, the landlord having entered to distrain, ${ }^{24}$ were

${ }^{n}$ Harburg India Rubber Co. v. Alartin, L. R. I K. B. 778 (1902).

${ }_{3} 3$ Burr. I886 (1766).

In a case brouglit shortly after the passage of the statute, Lord Lexington v. Clarke, 2 Ventris, 223 (2 W. \& M. in C. B.), the promise of a widow to pay rent due from her deceased husband to the plaintiff in consideration that the plaintiff would permit her to hold and enjoy the premises till our Lady-Day next and to permit her to remove divers posts, rails and other things fixed and placed upon the premises by her said husband was regarded as within the statute.

The explanation of the case may be that there was nothing in the nature of a bailment; for the willow, a tenant by sufferance, was in possession of both the land and the fixtures before she made the promise.

"The Statute of 8 Anne, c. I4, s. I, provided that "no goods or clattels whatsocver, lying or being in, or upon any messuage, lands, or tenements, which are or shall be leased for life or lives, term of years, or will, or otherwise, shall be liable to be taken by virtue of any execution, on any pretense whatsoever, unless the party at whose suit the said execution is sued out, shall before the removal of such goods from off the said premiscs, by virtue of such execution or ${ }^{\circ}$ extent pay to the landlord of the said premises, or his bailiff, all such sum or sums of moncy as are or shall be due for rent for the said premises at the time of the taking such goods or chattels, by virtue 
released by the landlord and turned over to the defendant upon his agreement to pay the rent due, 451 . to the plaintiff. As the goods sold for more than 451 , no question arose as to the extent of the defendant's liability. He defenrled on the ground that his promise to pay Taylor's debt was within the statute. Mr. Justice Wilmot, said: "Leper became the bailiff of the landlord; and when he had sold the goods the money was the landlord's (as far as 45l.) in his ore'n bailiff's hands.

Therefore an action would have lain against Leper for moncy had and received to the plaintiff's use."25

Lord Mansfield said: "This case has nothing to do with the statute of frauds . . . The goods are the fund: the question is not between Taylor and the plaintiff - "

We find confirmatory proof that the judges were here correctly reported by noting another report of Williams $\mathbf{v}$. Leper, by Serjeant IVilson (2 Wilson's Reports, p. 308): "Curia: This is not a promise to pay the debt of another, "the goods were debtor, and the defendant was in nature "of a bailiff for the landlord, and if the defendant had sold "the gonds and received money for them, an action for "money had and received for the plaintiff's use would have "lain in this case, except Aston, who thought if the goods "had not sold for so much money as the plaintiff's rent, he "would have been liable for no more than what they sold "for."

Castling v. Aubert, ${ }^{26}$ in 1802 , was an action on the case

of such exccutions, provided the said arrears of rent do not amount to more than one year's rent; and in case the said arrears shall exceed one year's rent. then the said party at whose suit the execution is sued out, paying the said landlord or his bailiff one year's rent, may procecd to exccute his judgment, as he might have done before the making of this act; and the sheriff or other officer is hereby empowered and required to levy and pay to the plaintiff as well the money so paid for rent, as the exccution money.

Sce also on point that a mamual taking is not necessary to begin a distress. Süran v. Folntouth, 8 B. \& .C. 456 (1828); Wood v. Nunn, 5 Bing. 10 (1828).

23 II'illiams v. Leper, 3 Burr. 1886 (1766).

${ }_{2}$ East, 325 (1802). 
to recover damages for breach of an agreement. "The plaintiff was under acceptances for Grayson for bills drawn by Grayson for his own accommodation: and plaintiff had a lien"on certain policies to indemmify himself against his said acceptances of certain bills which wcre made for Grayson's accommodation. One acceptance was due and a writ had been sued against Grayson and the plaintiff. Defendant promised plaintiff, if plaintiff would surrender the policies, to pay that acceptance with costs.

The Court of Iing's Bench unanimously decided that on the above facts there slould be a verdict for the plaintiff and that the statute was no defence. Lord Ellenborough, C. J., said: "It is rather therefore a purchase of the securities which the plaintiff held in his hands... . Upon the whole therefore I agree with the decision in Williams v. Leper, to the full extent of it: I agree with those of the judges who thought the case not within the statute of frauds at all: and I also agrce with the ground on which $\mathrm{Mr}$. Justice $\Lambda$ ston proceeded, that the evidence sustains the count for money had and received."

Lawrence, J., said: "This is to be considered as a purchase by the defendant of the plaintiff's interest in the policies." Le Blanc, J., said: "This is a case where one man having a fund in his hands which was adequate to the discharge of certain incumbrances; and another party undertook that if that fund were delivered up to him he would take it with the incumbrances; this therefore has no relation to the statute of frauds."2r

If the defendant made himself liable at all events he became a debtor ${ }^{28}$ and therefore the statute had no application. If he was mercly a bailee to sell and to render an account the statute would be equally inapplicable to a transaction which would be not a special promise to answer for the debt of another person but an accountability.

\footnotetext{
${ }^{n}$ Accord: Borchscuius v. Canutson, 100 Ill. 82 (188I).

$\Rightarrow$ See ante, note 20 .
} 
Lord Eldon's decision at Nisi Prius, in $1810,{ }^{29}$ is another application of the principle of Williams v. Leper. The plaintiff in the principal case had a common law lien for the repair of carriages and had charged the repairs to one C. The defendant agreed to pay the repair charge if the carriages should be delivered to him. After delivery and refusal to pay assumpsit was brought and the plaintiffs had a verdict. "If a person got goods into his possession" said Lord Eldon, "on which the landlord had a right to distrain for rent though it was clearly the debt of another, yet a note in writing was not necessary. . . . The plaintiffs had to a certain extent a lien upon the carriages, which they parted with on the defendant's promise to pay: that, he thought, took the case out of the statute."

Barrcl v. Trusscl, ${ }^{30}$ in 181 I, was an action upon a special agreement brought in the Common Pleas. The plaintiff being in possession of goods under a bill of sale and being about to sell them surrendered possession to the defendant, his vendor's landlord, upon the latter's verbal agreement to pay the plaintiff $\mathfrak{f}_{122}$, I9s., 6d. The plaintiff was permitted to recover.

In 1817, Edz'ards v. Kelly', 6 M. \& S. 204, presented substantially the same facts as IVilliams v. Leper. The defendants, Thomas Kelly and Brickwood, received goods which the plaintiff had previously distrained. The defendants agreed "to pay the plaintiff all such rent as should appear to be due to him from E. Kelly." The memorandum showing no consideration the Court treated the bailment as one by parol only. There was judgment for the plaintiff. The four opinions are significant. Lord Ellcuborough, C. J.: "Perhaps this case might be distinguishable from that of Williams v. Leper, if the goods distrained had not been delivered up to the defendants. But here was a delivery to them in trust, in effect to raise by sale of the goods sufficient to satisfy the plaintiff's demand:

\footnotetext{
Houlditch v. Milne, 3 Esp. 86.

"4 Taunt. 117 (1811).
} 
the goods were put into their possession subject to this trust. So that in substance this was an undertaking by the defendants that the fund should be available for the purpose of liquidating the arrears of rent."

Abbott, J.: "I am unable to distinguish this case in principle from Williams v. Lcpcr, and I find that case was recognized in Houlditch v. Milne and Castling v. Aubert. I think that this is not a promise to answer the debt of another."

Two of the justices (Holroyd and Bayley) relied upon the theory that "the debt was for the time suspended" by the distress. But this exceedingly narrow and technical view would limit recovery to cases of novation; which Castling v. Aubert certainly was not.

Nor can the writer assent to the distinction taken by Mr. Justice Bayley, in reference to the principal case, vis: that "it is stronger" than Williams v. Lcper, "because in that a distress had not been made, here the plaintiff had the distress in his hands." The statute, 8 Anne, c. 14, s. r, (ante note 24) was in force when Williams v. Leper was decided.

In 1827, in Bampton v. Paulin (12 Moore's Reports 497), the plaintiff was the landlord of a tenant in arrears. The landlord had apparently not entered but there were goods on the premises liable to distress, and "the plaintiff intended to distrain them for such arrears." The case is not sufficiently definite as to just what facts of the declaration were proved and what were not, but taking the declaration as proved the plaintiff though never in possession of the goods otherwise than constructively had a lien by virtue of the statute of 8 Anne, c. I4, s. I. The goods were taken away by the defendant in pursuance of an agreement with plaintiff to sell the goods and apply the proceeds to the rent. The Common Pleas (Best, C. J., Park, Borough and Gaselee, J. J.) decided the case by the analogy of the lien in Castling v. Aubcrt (supra) in favor of the plaintiff.

In Thomas v. Williams, ro B. \& C. 664 (1830), the decision turns on another point-the entirety of the promise- 
but the correctness of Edwards v. Kelly and of Castling v. Aitbert is admitted.

The decision of Tindal, C. J., at Nisi Prius, in 1834 , in I' alker v. Taylor (6 C. \& P. 752), is sufficiently dramatic to merit notice. The plaintiff was an undertaker and had agrecl with the widow of a publican who kept the King's Head, in Holborn, to bury her husband if she gave him sccurity for the bill. The widow accordingly gave the undertaker as security the beer and spirit licenses under which her late husband had operated. The defendant was the administrator of the decedent and was also his creditor. By agreement the plaintiff surrendered the beer and spirit licenses upon the defendant's personal assumpion of the lebt of his intestate. The defendant's objection that he could not be held on this verbal promise was overruled.

Exactly in accord with this view is another decision renlered in the same year by the Exchequer (Parke \& Alderson, B. B.), where the landlord being in possession of the tenant's effects under a distress for rent, agreed with the defendant, the tenant's assignee in bankruptcy, to withdraw the distress in exchange for the defendant's promise to pay the rent. The plaintiff having withdrawn the distress, the defendant having obtained possession of the goods was held liable on his verbal promise. Stephens v. Pell, $2 \mathrm{Cr}$. \& Mees. $710(1834)$.

Lord Tenterden, C. J., sees the action of Account as through a glass darkly when he observes: "There is no case in which the promise of payment has gone beyond the amount of the right vested in the party to whom the promise was made, or bcyond the assumed zalue of the fund out of a'hich the payment was to be made."

The complement of the recognition of the law of account in Williams v. Leper, is found in a decision of the Irish Exchequer, in $1845 .^{31}$ The plaintiff was the landlord and had made a distress. The defendant verbally promised to pay the rent due by one Carrigan, if the plaintiff would

"Fennel v. Mulcahy, 8 Irish Law Reports, 434 (I845). 
withdraw his distress. This was done. The defendant claimed the protection of the Statute. Brady, C. B., commenting on the opinion of Mr. Justice Wilmot, in Williams v. Lcper,", says: "He then adds what I consider to be important; 'Leper became the bailiff of the landlord, and when he had sold the goods, the money was the landlord's as far as $45 f$ in his own baliff's hands. Therefore an action would have lain against Leper for money had and received to the plaintiff's use.' Yates, J., seemed to think that there was an original consideration moving to the defendant. . . . That case contained matter not occurring here, because in this case the goods are not stated to have been assigned to the defendant or sold by him, and we must take it that in fact they were given back to Corrigan, and therefore there is no pretence for saying. that the defendant here was liable to the plaintiff in assumpsit as for money had and received."

In the same opinion Chief Baron Brady-speaking of $E d$ wards v. Kelly, ${ }^{33}$ reiterates the same position: "There the goods were delivered over to the person making the promise, by whom they were sold, and who undertook to pay over their produce, and the goods were in truth sold by the person who may be considcred as the bailiff of the party to whom the promise was made.". Finally, Brady, C. B., applying his test to the case in judgment said: "The first question here then is, what liability has the defendant. incurred? Plainly none, except on his promise. He did not become a trustee or bailiff for the plaintiff. No goods were left in his hands, or of the produce of which he was to pay this debt." "Nonsuit entered."

Fitzgerald v. Dressler, ${ }^{34}$ decided in 1859 , is a unanimous recognition by the Common Pleas that the delivery to the defendant of property upon which the plaintiff has a lien renders the defendant liable if he has orally agreed to dis-

${ }_{3}$ Burr. 1886 (1766).

*6 M. \& S. 204 (1817).

$\approx 7$ C. B. (N. S.) 374 (1859). 
charge the lien. Here the lien resulted from the antecedent and subsisting debt of a third person and that debt was not discharged.

Numerous American dẹcisions will likewise be found to the same effect that the surrender of property to the defenclant, on which the plaintiff has a lien, in exchange for the defendant's promise to pay the thus secured debt of a third person to the plaintiff is not a special promise to answer for the debt of another within the statute. ${ }^{35}$

The case of the del crcdere bailiff or factor is merely a particular species of accountability. The terms of any bailment to account are provable by parol. The defence was always permissible in Account before the auditors that although the goods had been sold that the vendee's debt was uncollcctible by the bailiff ${ }^{36}$ provided he had authority to sell on credit and not been negligent. ${ }^{37}$

A del credere factorship was merely one in which this. usual defence was by agreement denied to the bailee. The words, "No action shall be brought upon any special promise to answer for the debt, \&c., of another person" cannot properly apply to an action to enforce an accounting for the reason that the action of account is here brought on the bailment to account and there is no action brought upon

* There was no novation in any of the following cases: Grees v. Hadficld, 89 Wis. 138 (is94): Joseph, ct al., v. Simith, 57 N. W. (Neb.) Io12 (189.4); Adams v. Broan, 32 S. W. 282 (I895); s. c. 17 Ky. Law Reporter, 634: Alger v. Scozille, I Gray, 391 (1854).

The language of Shaw, C. J., in the last cited case is noteworthy because it is an echo of I'illians v. Leper: "this was a new and original contract between these parties, originating in a new consideration moving from the plaintiff to the defendant, in effect placing the funds in the hands of the defendiant out of which these notes in due course of business would be expected to be paid."

Compare, also, his previous opinion in Nelsoss v. Boynton, 3 Met. 306 ( $I R_{1} I$ ), where he held that a son's promise to pay his father's deht in consideration of forbearance to prosecute a pending suit therefor was within the statute. His sweeping dictum in Nelson v. Boyıton, so often quoted, "Cases are not considered as coming within the statute when the party promising has for his object a benefit which he did not before enjoy, accruing immediately to himself" should not be extended beyond the facts of that case.

* Barton v. Sadock, I Buls. 103 (I6ri) ; Anon., 2 Mod. 100 (1676).

"Leicrick v. Mcigs, I Cowen, 645 (1884). 
the guaranty. The guaranty is only one of the terms of the defendants' accountability.

Consistent with the above position are the decisions holding that a dcl credere factorship is not within the statute of frauds. ${ }^{38}$

The words of Parker, C. J., in $1828,{ }^{30}$ smacks of the language of Rolle, of Coke, of the judges in the Year Books: "The legal effect of such a contract is to make them liable at all events for the proceeds of the sale, so that according to some of the authorities, though denied by others, they may be charged on indebitatus assumpsit, or for goods sold to them. And there seems to be no reason why they should not be so charged, if upon receiving the goods thcy become accountable, except that their liability is not fixed until a sale is made. . . . But as the action cannot be sustained until after the sale has taken place, and then there is no legal excuse for not paying, the form of the action does not seem very material."

The language of Mr. Justice Cowen, in Wolff v. Koppel, ${ }^{40}$ is significant, echoing in 1843 principles of contract law which in the course of a hundred years had become somewhat faint. He said: "A guaranty though by parol is not always within the statute. . . . The merchant holds the goods and will not part with them to the factor without this extraordinary stipulation and a commission is paid to him for entering into it. What is this after all but another form of selling the goods? . . . Instead of paying cash the factor prefers to contract a debt or duty which obliges him to see the money paid. This debt or duty is his own . . . upon non-payment by the vendee, the debt falls absolutely on the factor ... . the action is in effest to recover the factor's own debt." . . .

\footnotetext{
${ }^{3}$ Couturier v. Hastic, $8 \mathrm{Ex} .40$ (1852); 9 Ex, 102 (1853). In Suman v. Inman, 6 Mo. App. 384 (1878), the court speaks of the debts due as on sales.

"Szian v. Nesmith, 7 Pick. 220 (1828).

${ }_{5} 5$ Hill (N. Y.) 458 (1843); affirmed in 2 Denio, 368.
} 
"The effect of the commission" (i. e., del credere), said Woodworth, J., in 1824, in Le'erick v. Meirs," "is not to extinguish the relation between principal and factor, but applies solely to a guaranty that the purchaser shall pay." In Conturicr v. IIastic, ${ }^{42}$ the Court of Exchequer held, in I 852, that a parol del cridcre factorship was not within the statute. Baron Parke, speaking for that Court, said: "Doubtless if they had for a percentage guarantied the delst owing or performance of the contract by the vendee being totally unconnected with the sale they would not be liable without a note in writing signed by them; but bcing the agcuts to negotiate the sale the commission is pail in respect of that employment. . . . This is the main object of the reward being given to them; and though it may terminate in a liability to pay the debt of another that is not the immediate object for which the consideration is given, and the case resembles in this respect those of Williams v. Leper, ${ }^{43}$ and Castling v. Aubert."4t

\section{Crawford D. Hening.}

\section{(To be Continued)}

\footnotetext{
"I Cowen 664 (I824).

“ 8 Exchequer Reports, 55 (1852).

Supra.

"Supra.
} 